\title{
Erratum to: About the structure of cellulose: debating the Lindman hypothesis
}

\author{
Wolfgang G. Glasser • Rajai H. Atalla $\cdot$ John Blackwell \\ R. Malcolm Brown Jr. • Walther Burchard • Alfred D. French • \\ Dieter O. Klemm • Patrick Navard • Yoshiharu Nishiyama
}

Published online: 18 April 2012

(C) Springer Science+Business Media B.V. 2012

\section{Erratum to: Cellulose \\ DOI 10.1007/s10570-012-9691-7}

Patrick Navard of the center for Materials Forming (Centre de Mise en Forme des Matériaux), MINES

The online version of the original article can be found under doi:10.1007/s10570-012-9691-7.

W. G. Glasser ( $\square)$

Department of Sustainable Biomaterials, Virginia Tech,

Blacksburg, VA, USA

e-mail: wglasser@vt.edu

\section{R. H. Atalla}

Chem. Biol. Eng., University of Wisconsin,

Madison, WI, USA

J. Blackwell

Department of Macromolecular Science and Engineering,

Case Western University, Cleveland, OH, USA

R. Malcolm Brown Jr.

Plant Cell Biology, University of Texas, Austin, TX, USA

W. Burchard

Institute of Macromolecular Chemistry,

University of Freiburg, Freiburg, Germany
ParisTech, CNRS, Sophia Antipolis, France, was inadvertently left off the list of authors in the original version of the paper. The first author apologizes for this oversight.

\author{
A. D. French \\ Southern Regional Research Center, ARS-USDA, \\ New Orleans, LA, USA \\ D. O. Klemm \\ Institute of Organic and Macromolecular Chemistry, \\ University of Jena, Jena, Germany \\ P. Navard \\ Center for Materials Forming (Centre de Mise en Forme \\ des Matériaux), MINES ParisTech, CNRS, Sophia \\ Antipolis, France \\ Y. Nishiyama \\ CERMAV-CNRS, Grenoble, France
}

